\title{
Antimicrobial Activity of a Cationic Guanidine Compound against Two Pathogenic Oral Bacteria
}

\author{
E. Escamilla-García, ${ }^{1,2}$ A. G. Alcázar-Pizaña, ${ }^{1,2}$ J. C. Segoviano-Ramírez, ${ }^{2,3}$ \\ C. Del Angel-Mosqueda, ${ }^{1,2}$ A. P. López-Lozano, ${ }^{1,2}$ E. Cárdenas-Estrada, ${ }^{2}$ \\ M. A. De La Garza-Ramos, ${ }^{1,2}$ C. E. Medina-De La Garza, ${ }^{2,3}$ and M. Márquez ${ }^{4}$ \\ ${ }^{1}$ Facultad de Odontología, Universidad Autónoma de Nuevo León, Monterrey, NL, Mexico \\ ${ }^{2}$ Centro de Investigación y Desarrollo en Ciencias de la Salud (CIDICS), Universidad Autónoma de Nuevo León, \\ Ave. Gonzalitos s/n con Ave. Dr. Carlos Canseco, Mitras Centro, 64460 Monterrey, NL, Mexico \\ ${ }^{3}$ Facultad de Medicina, Universidad Autónoma de Nuevo León, Monterrey, NL, Mexico \\ ${ }^{4}$ Department of Oncology-Pathology, CCK, Karolinska Institutet, 17176 Stockholm, Sweden
}

Correspondence should be addressed to E. Escamilla-García; erandi.escamillagrc@uanl.edu.mx and M. Márquez; marcela.marquez-holmberg@ki.se

Received 7 November 2016; Accepted 5 March 2017; Published 4 May 2017

Academic Editor: Barbara H. Iglewski

Copyright (C) 2017 E. Escamilla-García et al. This is an open access article distributed under the Creative Commons Attribution License, which permits unrestricted use, distribution, and reproduction in any medium, provided the original work is properly cited.

\begin{abstract}
This study evaluated the potential antimicrobial properties of a polyguanidine (CatDex) on two oral bacteria. Chlorhexidine gluconate $1340 \mu \mathrm{moL} \mathrm{L}^{-1}$ (CHX 0.12\%) was used as control. Streptococcus mutans (S. mutans) and Porphyromonas gingivalis (P. gingivalis) were grown in $\mathrm{BHI}$ media. Bacterial sensitivity and antimicrobial activity were determined by the minimum inhibitory concentration (MIC) and Kirby-Bauer methods. To study side effects, that is, toxicity, dental pulp stem cells (DPSCs) were used. Fluorometric cytotoxicity and confocal microscopy assays were used in order to test cell viability. CatDex inhibited growth of $S$. mutans at all concentrations and growth of $P$. gingivalis at all concentrations except $25 \mu \mathrm{moL} \mathrm{L} \mathrm{L}^{-1}$. The MIC of CatDex was $50 \mu \mathrm{moL} \mathrm{L}^{-1}$ for both $S$. mutans and $P$. gingivalis. The inhibition of bacteria exposed for $8 \mathrm{~h}$ at $50 \mu \mathrm{moL} \mathrm{L}^{-1}$ of CatDex exhibited increased antimicrobial activity over time, with $91 \%$ inhibition in both bacteria. The antimicrobial activities of CatDex and CHX were similar when tested on two common bacteria. CatDex was significantly less toxic to DPSCs. CatDex toxicity depended on time and not on concentration. With regard to clinical relevance, CatDex may have potential as a novel antimicrobial agent. Further studies are in progress.
\end{abstract}

\section{Introduction}

It is estimated that over $90 \%$ of the world's population suffer or have suffered from some kind of oral/dental disorder, including periodontal disease and caries [1]. P. gingivalis is considered to be the major etiological bacteria in the development of chronic periodontitis [2]. Dental caries is primarily caused by $S$. mutans. This and other bacteria can form biofilm or dental plaque [3]. Preventive measures against them include regular tooth brushing, flossing, fluoride therapy, fissure sealants, remineralisation of dental enamel, and antimicrobial agents [4]. Chlorhexidine gluconate (CHX) (Figure 1(a)) is used to prevent biofilm and remains the "gold standard" for oral antiseptics $[5,6]$. CHX is a safe material with low potential toxicity when used correctly, although it may produce some undesirable side effects such as discolouration of dental enamel, pigmentation of anterior restorations, irritation of oral mucosa, and taste alteration. Moreover, CHX gluconate may not be suitable for application to mucous membranes [7]. Cases of allergic reactions have also been recorded $[8,9]$.

CHX cytotoxicity has been demonstrated in various cell lines [8]. It can induce apoptosis at low concentrations, while high concentrations result in cell necrosis $[10,11]$. At certain concentrations, CHX appears to be toxic to human osteoblastic cells [12], odontoblast- like cells [13], and gingival 
<smiles>N=C(NCCCCCCNC(N)NC(=N)Nc1ccc(Cl)cc1)NC(=N)NC(=O)Nc1ccc(Cl)cc1</smiles>

(a)

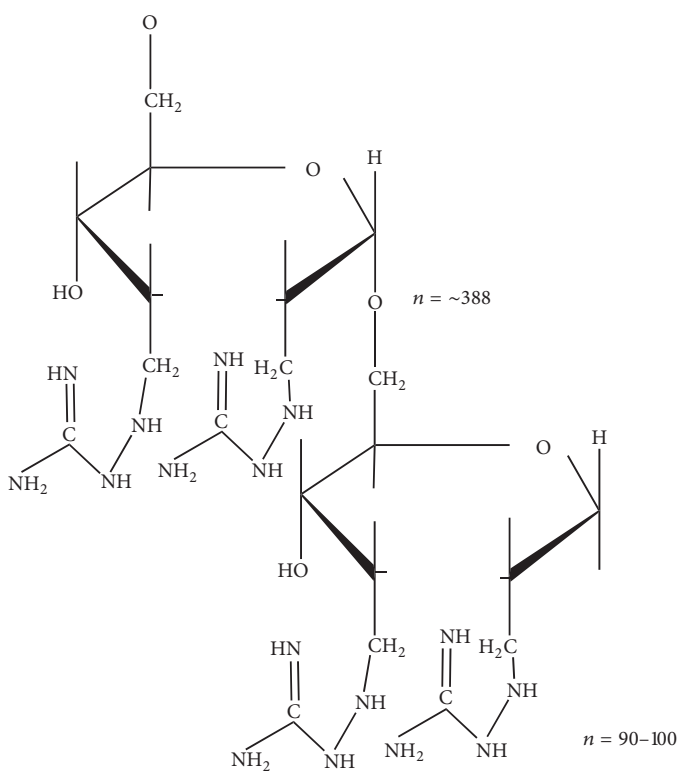

(b)

FIGURE 1: Chemical structure of chlorhexidine gluconate (CHX) (a) and CatDex (b).

fibroblasts. In addition, CHX may negatively affect wound healing [14].

CatDex is a polydisperse macromolecular construct with a molecular weight of $55 \mathrm{kD}$ and a carbohydrate backbone with multiple covalently coupled guanidine side groups distributed along the carbohydrate chains (Figure 1(b)). It has a cationic electrostatic charge with a wide $\mathrm{pH}$ range and it is hydrophilic. CatDex demonstrates potent antitumour efficacy in several tumour cell lines $[15,16]$. The proposed method of action in tumour cells is an electrostatic interaction with an anionic cell membrane, internalisation by the polyamine uptake system, and electrostatic binding of anionic structures in the cytoplasm, which kills the cell $[15,17]$. Similar to CatDex, but as a hydrogel, cationic synthetic dextran demonstrated antimicrobial activity against Escherichia coli (ATCC 25922) and Staphylococcus aureus (ATCC 25923) [18].

There are several similarities in proliferation, growth, and progression between tumour cells and bacteria: one similar feature is the electrostatic condition of their cell wall/membrane. In neoplastic cells, there is an overexpression of N-acetylneuraminic acid (Neu5Gc); therefore, the cell membrane is negatively charged [19]. In bacteria, the electronegative charge of the cell wall is due to lipopolysaccharides in Gram-negative bacteria and teichoic acid in Gram-positive organisms. These similarities and differences between CHX and CatDex (Table 1) led us to consider conducting a study involving oral pathogens.

CatDex has demonstrated strong antitumour cell efficacy; it is for this reason that we decided to determine whether or not it showed antimicrobial activity, in addition to assessing its toxicity and safety. This study included the use of Grampositive S. mutans UA130 and Gram-negative P. gingivalis
W83, two common oral bacteria associated with dental biofilm formation and periodontal disease.

\section{Materials and Methods}

2.1. Bacteria Culture. The strains used in this study were Streptococcus mutans UA130 (ATCC700611) and Porphyromonas gingivalis W83 (BAA308) as etiologic factors in periodontal disease and caries, the two most common oral diseases worldwide [1]. Culture and growth conditions for each bacterium were based on the technical specifications of the American Type Culture Collection (ATCC). S. mutans and $P$. gingivalis were subcultured at $37^{\circ} \mathrm{C}$ for $48 \mathrm{~h}$ on brain heart infusion agar plates (BHI, Becton Dickinson Bioxon $^{\circledR}$, Mexico). The bacteria were then inoculated to absorbance at $600 \mathrm{~nm}$ of 0.2 (Thermo Scientific GENESYS 10 UV Scanning Spectrophotometer, WI, USA) in Erlenmeyer flasks containing BHI medium. S. mutans and P. gingivalis were incubated for 6 and $23 \mathrm{~h}$, respectively, at $37^{\circ} \mathrm{C}$ until the cultures reached late logarithmic growth (Thermo Scientific Lab-Line Incubator, USA). The strain S. mutans was cultured under aerobic conditions at $37^{\circ} \mathrm{C}$. P. gingivalis was handled within an anaerobic chamber (Plas-Labs 855-ACB, Lansing, MI, USA), with an anaerobic atmosphere of $\mathrm{H}_{2}(10 \%), \mathrm{CO}_{2}$ (5\%), and $\mathrm{N}_{2}(85 \%)$ gas (Praxair, Mexico) at $37^{\circ} \mathrm{C}$. Culture media and material were presterilised for $15 \mathrm{~min}$ at $120^{\circ} \mathrm{C}$ (AllAmerican, Hillsville, USA). Before bacterial inoculation, the preculture was washed with $0.9 \% \mathrm{NaCl}(\mathrm{w} / \mathrm{v})$.

\subsection{CatDex Conjugate Preparation and FITC Labelling}

CatDex Synthesis. CatDex conjugate synthesis was performed as described previously [20]. Briefly, Dextran 70 Ph.Eur. (Pharmacosmos A/S, Denmark) was oxidised with sodium 
TABLE 1: Comparative table of the physicochemical and biological properties of CatDex and CHX.

\begin{tabular}{|c|c|c|}
\hline Characteristics & $\mathrm{CHX}$ & CatDex \\
\hline & Gold standard antiseptic & $?$ \\
\hline Solubility & Hydrophilic & Hydrophilic \\
\hline Charge & Cationic polybiguanide (polybiguanide) & Cationic \\
\hline Molecular weight & $1340 \mathrm{~g} \mathrm{moL}^{-1}$ & $55 \mathrm{KD}$ \\
\hline Density & $1.01 \mathrm{~g} \mathrm{cc}^{-1}$ & $?$ \\
\hline $\mathrm{pH}$ & $5.5-7.5$ & 6.5 \\
\hline Appearance & Blue translucent liquid & Amber translucent liquid \\
\hline Activity & $\begin{array}{c}\text { Bactericide } \\
\text { Fungicide } \\
\text { Antiviral }\end{array}$ & Antitumour efficacy $[15,16]$ \\
\hline Interaction with cells & $\begin{array}{c}\text { Electrostatic interaction with cationic } \\
\text { lipopolysaccharides and teichoic acid of cell wall [19] }\end{array}$ & $\begin{array}{c}\text { Electrostatic interaction with anionic structures of } \\
\text { cytoplasm }[15,17]\end{array}$ \\
\hline
\end{tabular}

periodate and aminoguanidine (Sigma-Aldrich, Sweden) and subsequently conjugated. Sodium cyanoborohydride (Aldrich, Sweden), was used for reductive amination. Disposable PD-10 columns with Sephadex G-25 (GE Healthcare, UK) were used for separation and purification. The conjugation yield was determined by analysis of the total nitrogen content (by Mikro Kemi AB, Uppsala, Sweden, elemental analysis, method-MK2062).

Fluorescein isothiocyanate (FITC) labelling of CatDex was prepared as described by Márquez et al. [16]. In brief, $40 \mu \mathrm{L}$ FITC solution (50 mg, Sigma-Aldrich, Sweden) was mixed with $1 \mathrm{~mL}$ dextran conjugate $(5 \mathrm{mg})$, all in $0.02 \mathrm{M}$ borate buffer at $\mathrm{pH} 9.5$. The solution was incubated overnight in a shaker in the dark and at room temperature and then purified on a PD-10 column equilibrated with PBS.

\subsection{Evaluation of the Antimicrobial Activity of CatDex against Two Oral Bacteria}

2.3.1. Disk Diffusion Method. Disk diffusion method and the Kirby-Bauer method were used to test antimicrobial effects [21]. A bacterial culture was prepared under the same conditions as those indicated above until it reached the exponential growth phase. Then, $100 \mu \mathrm{L}$ of inoculum was expanded onto BHI agar plates. A filter paper disk $(6 \mathrm{~mm})$ (Cat. number 1440-185, Whatman, Piscataway, USA) was embedded in $20 \mu \mathrm{L}$ of CatDex solution $\left(1,5,10,25,75\right.$, and $\left.120 \mu \mathrm{moL} \mathrm{L}^{-1}\right)$ and then placed on the agar surface. The positive control was $0.12 \%\left(1340 \mu \mathrm{moL} \mathrm{L}^{-1}\right)$ chlorhexidine gluconate $(\mathrm{CHX}$, Consepsis ${ }^{\circledR}$, USA), commonly used in dentistry as a topical disinfectant in rinses and mouthwash [22]. Saline solution $(0.9 \%)$ was used as a negative control. Culture plates were properly marked and incubated at $37^{\circ} \mathrm{C}$ for 24 to $48 \mathrm{~h}$ depending on bacteria growth requirements. Finally, the zone of inhibition around the disk was measured [23].

2.3.2. Minimum Inhibitory Concentration (MIC). The minimum inhibitory concentration method, considered the "gold standard," was used to determine the susceptibility of microorganisms to antimicrobial compounds [23]. The concentration range for CatDex was determined from concentrations used by precedent studies in different tumour cell lines [16]. CHX was used as a positive control and saline solution served as a negative control.

$S$. mutans and $P$. gingivalis were previously cultivated as described above. A concentration between $10 \times 10^{7}$ and $10 \times 10^{8}$ cells $/ \mathrm{mL}$ of both bacteria was inoculated in test tubes containing culture media and the testing compound was properly diluted to a final volume of $1 \mathrm{~mL}$ and incubated at $37^{\circ} \mathrm{C}$ for $24 \mathrm{~h}$.

2.3.3. Antimicrobial Effect of CatDex over Time. The antimicrobial effect of $50 \mu \mathrm{moL} \mathrm{L}{ }^{-1}$ (MIC value) CatDex on $S$. mutans and $P$. gingivalis was measured over $8 \mathrm{~h}$. This procedure was performed in order to obtain information about antimicrobial behaviour. Test tubes were inoculated as discussed above and were brought to a final volume of $1 \mathrm{~mL}$. Samples were incubated for $0 \mathrm{~min}$ and from 1 to $540 \mathrm{~min}$. Saline solution was used as a negative control. Absorbance at $600 \mathrm{~nm}$ and $\mathrm{pH}$ values were measured after incubation.

\subsection{Cytotoxicity Test}

2.4.1. Isolation and Culture of Dental Pulp Stem Cells (DPSCs). Tooth collection and experiments were conducted with the approval of the Ethics Committee of the School of Dentistry, Universidad Autónoma de Nuevo León, Mexico, and signed patient consent was obtained (0041-SS-010618). Procedures were performed in accordance with the World Medical Association's Declaration of Helsinki of 1964 and subsequent revisions.

Dental pulp tissue was collected from human premolars and dissociated with $3 \mathrm{mg} \mathrm{mL}^{-1}$ collagenase type I and $4 \mathrm{mg} \mathrm{mL}^{-1}$ dispase (Sigma-Aldrich, USA) for $1 \mathrm{~h}$ at $37^{\circ} \mathrm{C}$. The cell sample was centrifuged for $10 \mathrm{~min}$ at $300 \mathrm{~g}$ and filtered through a $70 \mu \mathrm{m}$ nylon filter (Millipore, Bedford, USA).

The DPSCs were cultivated for 3 weeks in $\alpha$-modified Eagle's Medium ( $\alpha$-MEM) (Gibco, Invitrogen, Carlsbad, USA), containing $10 \%$ foetal bovine serum (FBS) and $1 \%$ antibiotic-antimycotic (Sigma-Aldrich). Cells were incubated at $37^{\circ} \mathrm{C}$ in a humidified atmosphere with $5 \% \mathrm{CO}_{2}$ [24]. 


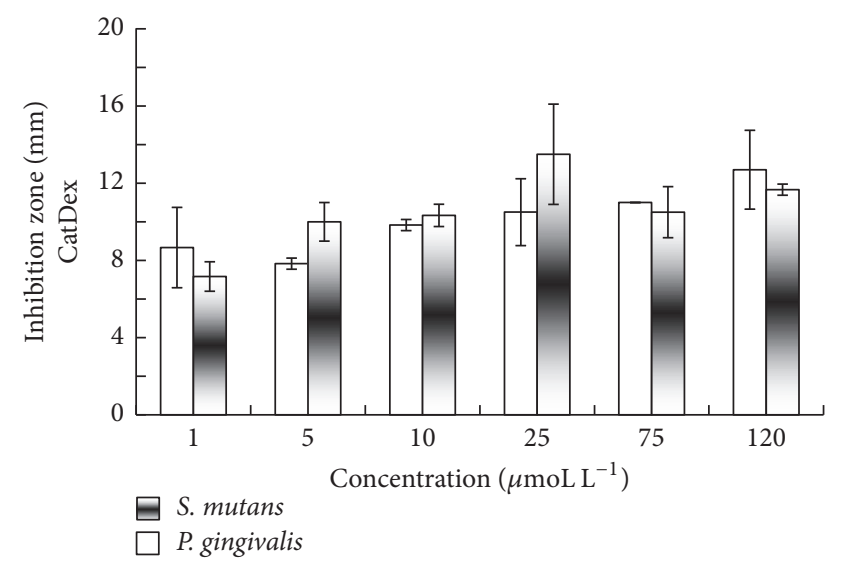

(a)

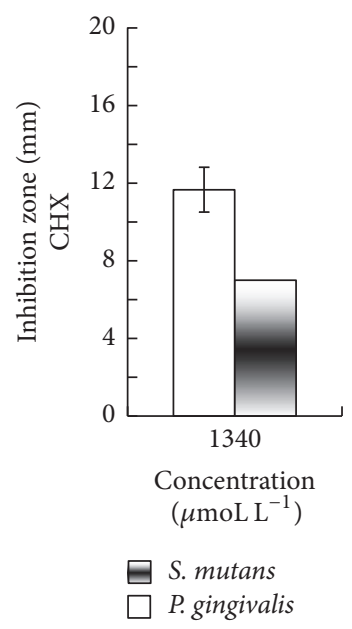

(b)

FIGURE 2: Determination of the bacterial susceptibility to CatDex (a) and CHX (b) of strains S. mutans UA130 and P. gingivalis W83. Significant differences between CatDex and CHX were observed at all concentrations for both bacteria $(p<0.05)$ except at 1,25 , and $120 \mu \mathrm{moL} \mathrm{L}{ }^{-1}$.

2.4.2. Fluorometric Microculture Cytotoxicity Assay (FMCA). This assay was performed as described by Larsson and Nygren [25]. The cytotoxicity of CatDex was tested on DPSCs cultivated in D-MEM containing 10\% FBS and antibioticantimycotic. Briefly, $20 \times 10^{3}$ cells per well were seeded into 96-well microtitre plates (Falcon, Becton Dickinson, France). CatDex was added at concentrations ranging from 10 to $120 \mu \mathrm{moL} \mathrm{L}^{-1}$ and $\mathrm{CHX}$ was added at $1340 \mu \mathrm{moLL}^{-1}$ as a positive control; PBS was used as a negative control. After $24 \mathrm{~h}$ incubation, medium was removed by flicking the plates. Cells were washed three times with PBS. Fluorescein diacetate (FDA, Sigma) was dissolved in DMSO (Sigma-Aldrich) and kept frozen at $-20^{\circ} \mathrm{C}$ as stock solution $\left(10 \mathrm{mg} \mathrm{mL}^{-1}\right)$. FDA was diluted in PBS at $10 \mu \mathrm{g} \mathrm{mL}^{-1}$, and $200 \mu \mathrm{L}$ was added to each well. Plates were then incubated for $30 \mathrm{~min}$ at $37^{\circ} \mathrm{C}$. A 96-well GloMax ${ }^{\circledR}$-Multi+ Microplate Multimode scanning fluorometer (Promega, Madison, USA) was used at $495 \mathrm{~nm}$. Data were analysed to determine cell viability (\%).

2.4.3. Cytotoxic Effect of CatDex over Time. The cytotoxicity test was performed as follows: $20 \times 10^{4}$ cells per well were seeded into 96 -well microtitre plates in media under conditions as described above for $24 \mathrm{~h}$. Then CatDex $\left(50 \mu \mathrm{moL} \mathrm{L}{ }^{-1}\right.$ final concentration) was added and cells were incubated from 1 to $240 \mathrm{~min}(4 \mathrm{~h})$, and the cytotoxic effect was measured by the FMCA method.

2.4.4. Preparation of DPSCs Culture in a Coverglass System. DPSCs were seeded into eight wells in sterile chamber slides at $2 \times 10^{5}$ cell well $^{-1}$ (Chambered \# German Coverglass System, Lab-Tek ${ }^{\circledR}$ II) with final volume of $400 \mu \mathrm{L}$. A culture of DPSCs was made for $24 \mathrm{~h}$ as described above. Afterwards, CatDex or CHX was added with a final concentration of $50 \mu \mathrm{mol} \mathrm{L}^{-1}$ and $550 \mu \mathrm{mol} \mathrm{L}^{-1}$, respectively, that is, matching number of moles of each molecule. The cells were incubated for 1 and $5 \mathrm{~h}$ and MitoTracker ${ }^{\circledR}$ Red CM- $\mathrm{H}_{2}$ XRos dye $\left(300 \mathrm{nmol} \mathrm{L}^{-1}\right.$ ) was added $30 \mathrm{~min}$ before the incubation time ended. Cells incubated with chlorhexidine at commercially used concentrations acted as a positive control and a negative control was provided by cells incubated in culture media without any other compound. After incubation, supernatant was removed and cells were fixed with $10 \%$ formaldehyde for $10 \mathrm{~min}$ and washed twice with PBS. Then $1 \mu \mathrm{g} \mathrm{mL}^{-1}$ DAPI dye was added. Morphological analysis was performed by confocal laser microscopy (Axio Observer Z1/LSM 700, Zeiss) using Zen 2009 software and a 63x objective. MitoTracker, DAPI, and FITC dyes were excited with 561, 405, and $488 \mathrm{~nm}$ laser, respectively, at $2 \mathrm{mV}$.

2.5. Statistical Analysis. All experiments were performed in triplicate $(n=3)$. Mean values and standard deviation (SD) were calculated. Significant differences between CatDex and CHX were evaluated using Student's $t$-test $(p \leq 0.05)$.

\section{Results}

3.1. Sensitivity Test. The inhibitory effect of CatDex disk diffusion on both bacteria is shown in Figure 2. With CatDex, the mean zone of inhibition (SD) was $13.5 \mathrm{~mm} \pm$ 2.59 at $25 \mu \mathrm{moLL}^{-1}$ for $S$. mutans and $12.7 \mathrm{~mm} \pm 2.04$ at $120 \mu \mathrm{moL} \mathrm{L}^{-1}$ for P. gingivalis (Figure 2(a)). The mean results (SD) with $\mathrm{CHX}$ were $7 \mathrm{~mm} \pm 0.00$ and $11.7 \mathrm{~mm} \pm 1.15$ at $1340 \mu \mathrm{moL} \mathrm{L}^{-1}$, respectively (Figure 2(b)). S. mutans was significantly more sensitive to CatDex than CHX at all tested concentrations $(p \leq 0.05)$. There was a significant difference between CatDex and CHX in P. gingivalis at $5 \mu \mathrm{moL} \mathrm{L}^{-1}(p \leq$ 0.05).

3.2. Minimum Inhibitory Concentration (MIC). The MIC was used to extend the results of the sensitivity test (Figure 3). Mean absorbance $\left(A_{600 \mathrm{~nm}}\right)(\mathrm{SD})$ of $S$. mutans and $P$. gingivalis cultures after $24 \mathrm{~h}$ of incubation at $37^{\circ} \mathrm{C}$ was $0.78 \pm 0.02$ and $1.15 \pm 0.11$, respectively. Final mean $\mathrm{pH}$ values $(\mathrm{SD})$ were $5 \pm 0.12$ and $6 \pm 0.32$ for $S$. mutans and P. gingivalis (data not shown). CatDex showed $\sim 100 \%$ bacterial inhibition at 


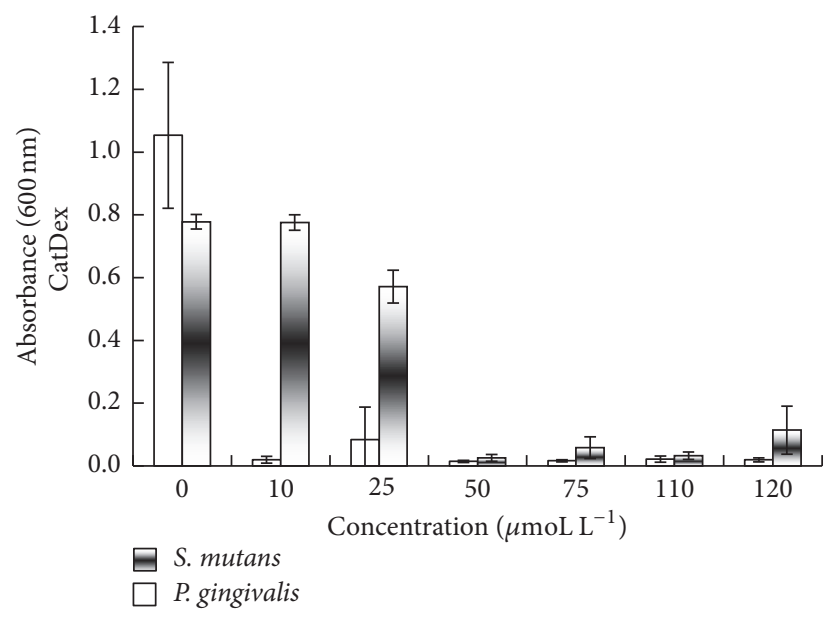

(a)

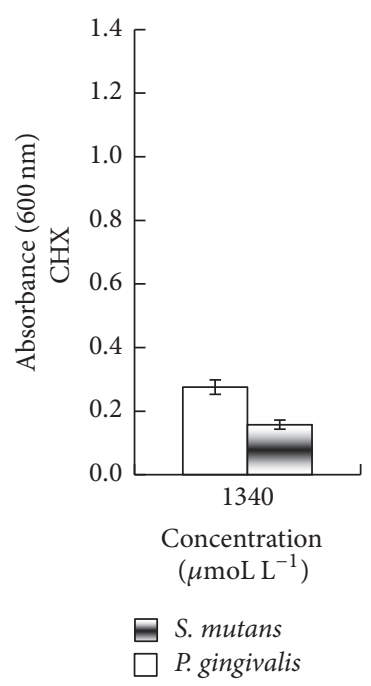

(b)

FIgURE 3: Determination of the minimum inhibitory concentration (MIC) of CatDex (a) and CHX (b) against $S$. mutans UA130 and P. gingivalis W83 $(p \leq 0.05)$. At all concentrations, CatDex showed a significant impact on $S$. mutans, and $P$. gingivalis growth also demonstrated a similar effect except at $25 \mu \mathrm{moL} \mathrm{L}{ }^{-1}$, both compared to CHX $1340 \mu \mathrm{moL} \mathrm{L}^{-1}(p<0.05)$.

$>50 \mu \mathrm{moL} \mathrm{L}^{-1}$ (pH 7.1) for S. mutans and at $>10 \mu \mathrm{moL} \mathrm{L}^{-1}$ for P. gingivalis (Figure 3(a)). Bacterial inhibition with $\mathrm{CHX}$ at $1340 \mu \mathrm{moL} \mathrm{L}{ }^{-1}$ (Figure 3(b)) was 79\% for S. mutans (pH 7.34). The effect on $P$. gingivalis was $76 \%$ inhibition ( $\mathrm{pH} 7.41$ ).

MIC results with CatDex and CHX showed significant differences at all concentrations for S. mutans. For P. gingivalis, there were significant differences at all concentrations except $25 \mu \mathrm{moL} \mathrm{L}{ }^{-1}(p \leq 0.05)$.

3.3. Antimicrobial Effect of CatDex over Time. CatDex was tested at $50 \mu \mathrm{moL} \mathrm{L}{ }^{-1}$ after MIC results in both bacteria (Figure 4). After the first minute, CatDex reduced the mean (SD) numbers of both bacteria by $31 \% \pm 2.0$ (pH 7.11). CatDex inhibition increased with time up to $91 \%$ at $480 \mathrm{~min}$. CatDex showed a higher effect on $P$. gingivalis at $240 \mathrm{~min}(4 \mathrm{~h})$ than on S. mutans.

3.4. CatDex Cytotoxicity Evaluation. The CatDex cytotoxicity test results are shown in Figure 5. The mean (SD) viability of DPSCs after $24 \mathrm{~h}$ of exposure to CatDex ranged from $34 \% \pm 3.70$ to $38 \% \pm 2.96$ at concentrations between 10 and $120 \mu \mathrm{moL} \mathrm{L}^{-1}$, respectively, as shown in Figure 5(a). The mean (SD) viability of DPSCs after $24 \mathrm{~h}$ of exposure to CHX at $1340 \mu \mathrm{moL} \mathrm{L}^{-1}$ was $5.01 \pm 0.157$ (Figure 5(b)).

The MIC concentrations of CatDex $\left(50 \mu \mathrm{moL} \mathrm{L}{ }^{-1}\right)$ for $S$. mutans and $P$. gingivalis were tested at different incubation times (see Figure 5(c)). In the first minute, we observed mean (SD) cell viability of $83 \% \pm 1.53$. The mean (SD) viability decreased gradually with time of exposure: from $80 \% \pm 3.51$ at $5 \mathrm{~min}$ to $44 \% \pm 1.32$ at $240 \mathrm{~min}$ of exposure to CatDex, with $50 \% \pm 0.76$ and $44 \% \pm 1.32$ of viability for $S$. mutans and $P$. gingivalis, respectively.

3.5. Cytotoxic Effect and Morphological Changes on DPSCs. Figure 6 shows the effect on viability of DPSCs exposed to

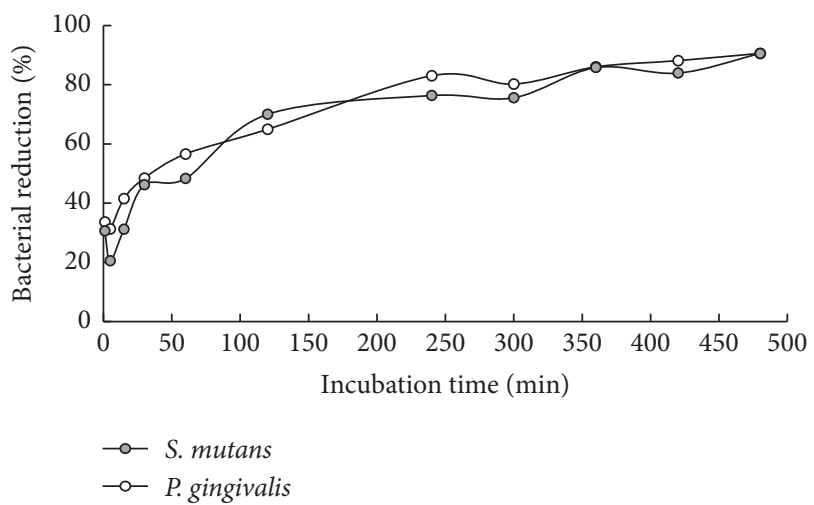

Figure 4: Antibacterial effect at $50 \mu \mathrm{moL} \mathrm{L}{ }^{-1}$ of CatDex. Percentage of bacterial reduction of $S$. mutans UA130 and P. gingivalis $W 83$ over time $(p \leq 0.05)$.

CatDex-FITC $\left(0.05 \mu \mathrm{mol} \mathrm{L}^{-1}\right)$ for 0,1 , and $5 \mathrm{~h}$. In the negative control (Figure 6(a)), cellular morphology is normal, with sizes between 50 and $100 \mu \mathrm{m}$ in their major diameter and between 10 and $40 \mu \mathrm{m}$ in their minor diameter; they exhibit adherent cytoplasm extensions that end in thin threadlike processes, which lends a starry appearance to the cell. The nucleus was round or oval with a smooth surface and a diameter of about $20 \times 30 \mu \mathrm{m}$. Dispersed chromatin in blue by DAPI staining was observed. Cytoplasm was starry irregular or fusiform. Abundant mitochondria profiles, circular, oval, or elongated, in red colour were seen by MitoTracker.

The positive control with CHX (Figure 6(e)) shows chromatin condensation, pyknosis, and nuclear disorganisation, along with mitochondrial disintegration, decreased MitoTracker signaling, and cytoplasmic disorganization, with MitoTracker discharge to culture medium. The effect of CatDex is shown in Figures 6(b), 6(c), and 6(d) at 0, 1, and 


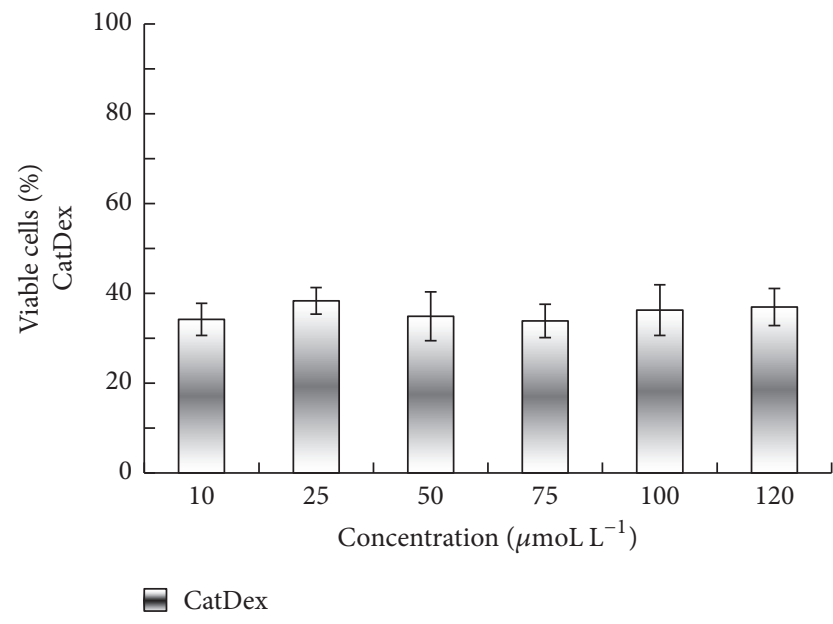

(a)

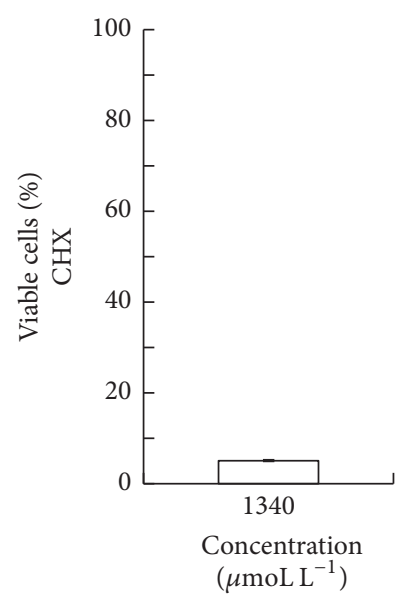

(b)

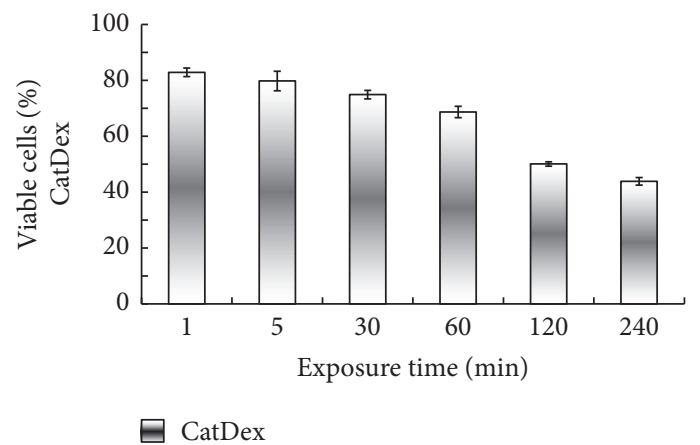

(c)

Figure 5: Cytotoxic effect at different concentrations of CatDex and CHX for $24 \mathrm{~h}$ at $50 \mu \mathrm{moL} \mathrm{L}{ }^{-1}$ (a) and $1340 \mu \mathrm{moL} \mathrm{L}{ }^{-1}$ (b), respectively, and for $240 \mathrm{~min}$ (c) on dental pulp stem cells (DPSCs). No correlation was found between viable cell percentage and CatDex concentration $(p<0.05)$.

$5 \mathrm{~h}$ of exposure, respectively. Cells retained normal morphological appearance (Figure 6(a)) independent of incubation time. Green fluorescence from FITC is observed in the cells' cytoplasm: this signal apparently decreased over time. MitoTracker signal was observed in the perinuclear region of the cytoplasm and is colocalised with the green signal of FITC.

Contrast images from Figures 6(f), 6(g), and 6(h) describe the effect on similar cultures of CHX over time. At time zero (Figure 6(f)), cells showed a morphological appearance similar to that of the positive control. After 1 and $5 \mathrm{~h}$ of exposure to $\mathrm{CHX}$, the cells showed a cytoplasm of circular appearance and decreased membrane extensions, in addition to an irregular surface and a heterogeneous texture with round red agglomerates of variable size. The nucleus is decreased in size with folding in its surface and condensed chromatin, which gives a pyknotic appearance. This change is more pronounced at $5 \mathrm{~h}$ of exposure.

\section{Discussion}

We tested the possible antimicrobial properties of CatDex against the bacteria $S$. mutans and $P$. gingivalis and its toxicity towards DPSCs. CatDex demonstrated antimicrobial effects against these two bacteria, especially $P$. gingivalis. $\mathrm{CHX}$ is a commonly used antiseptic with broad-spectrum activity against a large number of oral microorganisms. It is less effective against Gram-negative microorganisms due to the lipopolysaccharides (LPS) found in the cell membrane of these microorganisms [26].

$\mathrm{CHX}$ is an agent with multiple amine and imine groups. It contains a cationic charge that interacts electrostatically with anionic structures of the bacterial membrane wall. CHX destabilises the cell wall and interferes with osmosis; this mechanism of action is found in many cationic agents [7, 27]. CatDex is a polyguanidine compound that is more stable than $\mathrm{CHX}$ and has a strong cationic electrostatic charge at a broad $\mathrm{pH}$ interval. CatDex and $\mathrm{CHX}$ both have a cationically charged molecule that binds anionic groups and it is reasonable to assume that they act upon bacteria in a similar way. It is well known that CHX is bacteriostatic at low concentrations and bactericidal at high concentrations and that it is less effective against Gram-negative organisms [28]. CHX is more effective at an alkaline $\mathrm{pH}$ and its activity is greatly reduced in the presence of organic matter [29]. At high temperatures, CHX decomposes into chloroaniline, which 


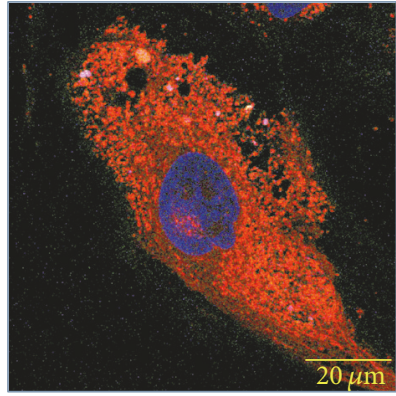

(a)

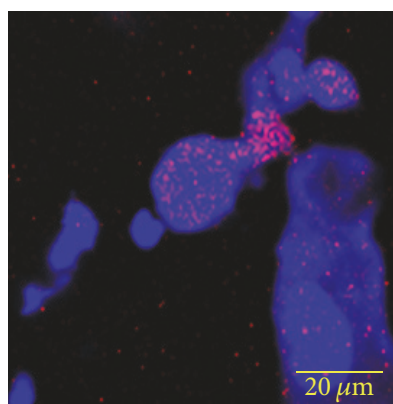

(e)

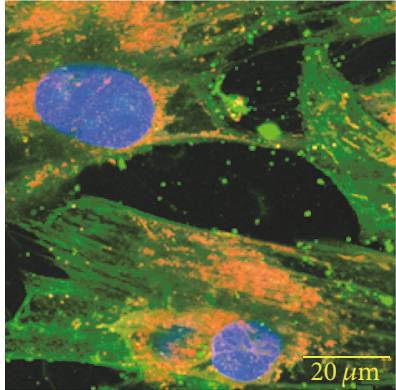

(b)

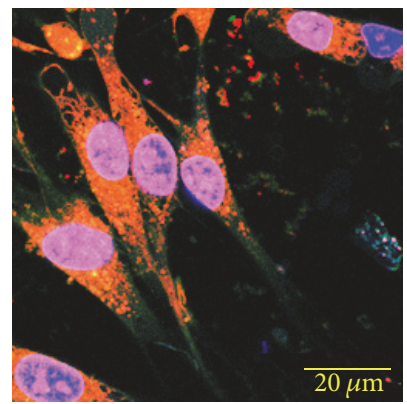

(f)

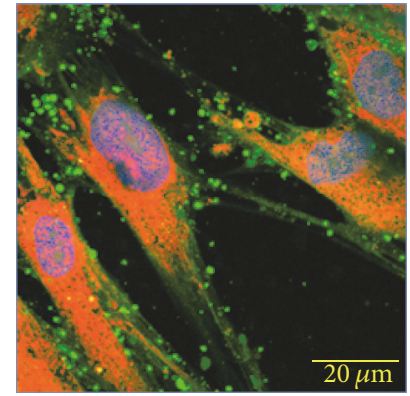

(c)

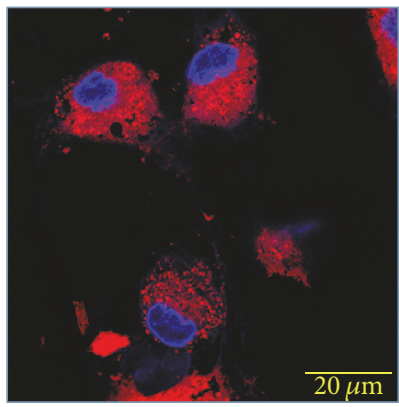

(g)

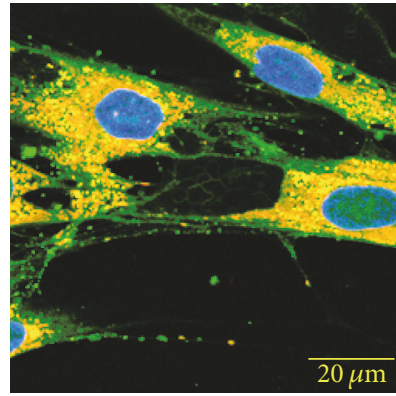

(d)

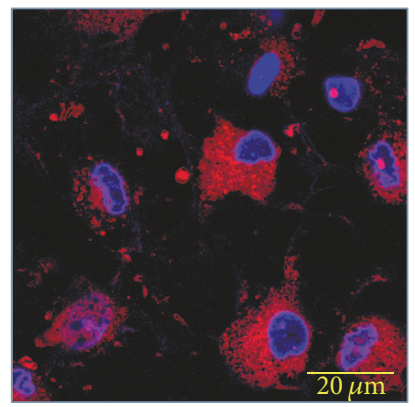

(h)

Figure 6: Cytotoxic effect on cultured dental pulp stem cells (DPSCs) exposed to $50 \mu \mathrm{moL} \mathrm{L}^{-1}$ CatDex-FITC and CHX for different amounts of time. (a) Negative control; (e) positive control. (b), (c), and (d): CatDex-FITC at $3 \mathrm{sec}, 1 \mathrm{~h}$, and $5 \mathrm{~h}$, respectively. (f), (g), and (h): chlorhexidine at $3 \mathrm{sec}, 1 \mathrm{~h}$, and $5 \mathrm{~h}$, respectively. In red, emission of MitoTracker- $\mathrm{H}_{2}$ XRos staining mitochondria; in blue, DAPI signal localised to the nuclear compartment; in green, CatDex-FITC signal localised to cytoplasm; and in orange, colocalisation of MitoTracker and FITC signals. Confocal laser microscope, fluorescent, histochemical technique, and objective $63 \mathrm{x}$.

may explain its maximal action only in the first minutes of contact with bacteria [30].

Antibiotics and other antibacterial substances do not easily penetrate the outer membrane of Gram-negative bacteria because of their hydrophobic components. Antibiotics, which are active against Gram-positive bacteria, are often much less active against Gram-negative bacteria [26]. CatDex showed an inhibitory effect on bacterial growth which was dependent on concentration and exposure time. CatDex showed gradual and sustained inhibition for up to $8 \mathrm{~h}$ for both bacteria, which can be explained by the high stability of the CatDex molecule.

With regard to cytotoxicity, $\mathrm{CHX}$ has been shown to be less toxic to fibroblasts and keratinocytes compared to $\mathrm{H}_{2} \mathrm{O}_{2}$ and $\mathrm{NaClO}$ [31], and its toxic potency is dependent on length of exposure and medium composition [32]. Most studies have shown that $\mathrm{CHX}$ tends to damage different cell lines such as osteoblastic, endothelial, and fibroblastic cells [33]; furthermore, a recent study demonstrated CHX's toxic effect on stem cells from human exfoliated deciduous teeth at similar therapeutic concentrations over different periods of time [34]. Our results showed CatDex to be significantly less toxic to DPSCs than CHX, with a comparable antimicrobial effect towards both bacteria.

Cytotoxicity on DPSCs was different between CatDex and CHX even after $5 \mathrm{~h}$ of exposure: morphologically, the integrity of DPSCs exposed to CatDex was maintained, whereas CHX caused evident cellular damage. We concluded that CHX is significantly more toxic than CatDex.

In the search for an ideal endodontic irrigant with the four major desirable properties (antimicrobial activity, nontoxicity, water solubility, and capacity to dissolve organic matter), our results and literature [20] show that CatDex more than meets most of these criteria.

\section{Conclusion}

CatDex has an antimicrobial effect on $S$. mutans and $P$. gingivalis similar to that of $\mathrm{CHX}$. CHX cell toxicity was dependent on concentration and time, while CatDex toxicity depended only on time. CatDex was less toxic to DPSCs over long exposure times and did not alter cell morphology. With the growing evidence of the potential involvement of oral bacteria in the pathogenesis of upper digestive tract neoplasia [35], studies of new antibacterial compounds, even with known antitumour agents such as CatDex, are further warranted.

\section{Ethical Approval}

All procedures performed in studies involving human participants were done in accordance with the ethical standards of the institutional research committee (School of Dentistry, 
Universidad Autónoma de Nuevo León) and with the 1964 Declaration of Helsinki and its subsequent revisions or comparable ethical standards.

\section{Consent}

Informed consent for tooth collection was obtained from all individual participants included in the study (0041-SS010618).

\section{Disclosure}

An earlier version of this work was presented as a poster in the International Association for Dental Research (IADR) meeting in Seattle, USA, in 2013.

\section{Conflicts of Interest}

The authors report no conflicts of interest.

\section{Acknowledgments}

The authors wish to thank Marvin M. Maltez for language suggestions and Professor Richard J. Lamont for critically reading the manuscript. They are also grateful to Mr. Patrick Bennett Weill for his assistance with English language editing. This work was supported by Proinnova-CONACyT (Grant no. 141616), Esteripharma de México, S.A., the Cancer Society in Stockholm, the King Gustaf V Jubilee Fund (Stockholm), and the Swedish Cancer Society.

\section{References}

[1] WHO, Oral Health, World Health Organization, 2012.

[2] N. Abe, T. Kadowaki, K. Okamoto, K. Nakayama, M. Ohishi, and K. Yamamoto, "Biochemical and functional properties of lysine-specific cysteine proteinase (Lys-Gingipain) as a virulence factor of Porphyromonas gingivalis in periodontal disease," The Journal of Biochemistry, vol. 123, no. 2, pp. 305-312, 1998.

[3] A. F. P. Leme, H. Koo, C. M. Bellato, G. Bedi, and J. A. Cury, “The role of sucrose in cariogenic dental biofilm formation-new insight," Journal of Dental Research, vol. 85, no. 10, pp. 878-887, 2006.

[4] J. E. Frencken, M. C. Peters, D. J. Manton, S. C. Leal, V. V. Gordan, and E. Eden, "Minimal intervention dentistry for managing dental caries-a review: report of a FDI task group," International Dental Journal, vol. 62, no. 5, pp. 223-243, 2012.

[5] M. G. Jorgensen, A. Aalam, and J. Slots, "Periodontal antimicrobials-finding the right solutions," International Dental Journal, vol. 55, no. 1, pp. 3-12, 2005.

[6] M. Puig-Silla, J. Montiel-Company, and J. Almerich-Silla, "Use of chlorhexidine varnishes in preventing and treating periodontal disease: a review of the literature," Medicina Oral, Patología Oral y Cirugía Bucal, vol. 13, no. 4, pp. E257-E260, 2008.

[7] M. Okano, M. Nomura, S. Hata et al., "Anaphylactic symptoms due to chlorhexidine gluconate," Archives of Dermatology, vol. 125, no. 1, pp. 50-52, 1989.

[8] J. J. Pucher and C. Daniel, "The effects of chlorhexidine digluconate on human fibroblasts in vitro," Journal of Periodontology, vol. 63, no. 6, pp. 526-532, 1992.
[9] M.-F. Wang, L. E. Marks, and M. E. Frank, "Taste coding after selective inhibition by chlorhexidine," Chemical Senses, vol. 34, no. 8, pp. 653-666, 2009.

[10] G. Faria, M. R. N. Celes, A. De Rossi, L. A. B. Silva, J. S. Silva, and M. A. Rossi, "Evaluation of chlorhexidine toxicity injected in the paw of mice and added to cultured L929 fibroblasts," Journal of Endodontics, vol. 33, no. 6, pp. 715-722, 2007.

[11] E. Moka, E. Argyra, I. Siafaka, and A. Vadalouca, "Chlorhexidine: hypersensitivity and anaphylactic reactions in the perioperative setting," Journal of Anaesthesiology Clinical Pharmacology, vol. 31, no. 2, pp. 145-148, 2015.

[12] T.-H. Lee, C.-C. Hu, S.-S. Lee, M.-Y. Chou, and Y.-C. Chang, "Cytotoxicity of chlorhexidine on human osteoblastic cells is related to intracellular glutathione levels," International Endodontic Journal, vol. 43, no. 5, pp. 430-435, 2010.

[13] F. C. R. Lessa, A. M. F. Aranha, I. Nogueira, E. M. A. Giro, J. Hebling, and C. A. D. S. Costa, "Toxicity of chlorhexidine on odontoblast-like cells," Journal of Applied Oral Science, vol. 18, no. 1, pp. 50-58, 2010.

[14] A. J. Mariotti and D. A. H. Rumpf, "Chlorhexidine-induced changes to human gingival fibroblast collagen and non-collagen protein production," Journal of Periodontology, vol. 70, no. 12, pp. 1443-1448, 1999.

[15] M. Márquez, J. Du, M. Edgren et al., "Development of dextran derivatives with cytotoxic effects in human urinary bladder cancer cell lines," Anticancer Research, vol. 22, no. 2, pp. 741-744, 2002.

[16] M. Márquez, S. Nilsson, L. Lennartsson et al., "Chargedependent targeting: results in six tumor cell lines," Anticancer Research, vol. 24, no. 3, pp. 1347-1352, 2004.

[17] S. R. Deka, A. K. Sharma, and P. Kumar, "Cationic polymers and their self-assembly for antibacterial applications," Current Topics in Medicinal Chemistry, vol. 15, no. 13, pp. 1179-1195, 2015.

[18] N. A. O’Connor, A. Abugharbieh, F. Yasmeen et al., “The crosslinking of polysaccharides with polyamines and dextranpolyallylamine antibacterial hydrogels," International Journal of Biological Macromolecules, vol. 72, no. 1, pp. 88-93, 2015.

[19] N. M. Varki and A. Varki, "Diversity in cell surface sialic acid presentations: implications for biology and disease," Laboratory Investigation, vol. 87, no. 9, pp. 851-857, 2007.

[20] L. Meurling, M. Márquez, S. Nilsson, and A. R. Holmberg, "Polymer-conjugated guanidine is a potentially useful antitumor agent," International Journal of Oncology, vol. 35, no. 2, pp. 281-285, 2009.

[21] A. W. Bauer, W. M. Kirby, J. C. Sherris, and M. Turck, "Antibiotic susceptibility testing by a standardized single disk method," American Journal of Clinical Pathology, vol. 45, no. 4, pp. 493496, 1966.

[22] G. Calsina-Gomis and J. Serrano-Granger, "Are there any differences between different concentrations of clorhexidine? Comparison of mouthrinses," Riverside County Office of Education, vol. 10, no. 4, pp. 457-464, 2016.

[23] J. M. Andrews, "Determination of minimum inhibitory concentrations," Journal of Antimicrobial Chemotherapy, vol. 48, no. 1, pp. 5-16, 2001.

[24] C. Del Ángel-Mosqueda, Y. Gutiérrez-Puente, A. P. LópezLozano et al., "Epidermal growth factor enhances osteogenic differentiation of dental pulp stem cells in vitro," Head and Face Medicine, vol. 11, no. 1, article 29, 9 pages, 2015. 
[25] R. Larsson and P. Nygren, "A rapid fluorometric method for semiautomated determination of cytotoxicity and cellular proliferation of human tumor cell lines in microculture," Anticancer Research, vol. 9, no. 4, pp. 1111-1120, 1989.

[26] K. Yasuda, C. Ohmizo, and T. Katsu, "Mode of action of novel polyamines increasing the permeability of bacterial outer membrane," International Journal of Antimicrobial Agents, vol. 24, no. 1, pp. 67-71, 2004.

[27] A. J. Mangram, T. C. Horan, M. L. Pearson et al., "United States CDC: guideline for prevention of surgical site infection," Hospital Infection Control and Prevention-Hospital Infection Control Practices, vol. 20, no. 4, pp. 97-132, 1999.

[28] G. McDonnell and AD. Russell, "Antiseptics and disinfectants: activity, action and resistance," Clinical Microbiology Reviews, vol. 12, no. 1, pp. 147-179, 1999.

[29] A. D. Russell and F. R. C. Path, "Chlorhexidine: antibacterial action and bacterial resistance," Infection, vol. 14, no. 5, pp. 212$215,1986$.

[30] L. E. Barbin, C. Estrela, D. F. C. Guedes, J. C. E. Spanó, M. D. Sousa-Neto, and J. D. Pécora, "Detection of para-chloroaniline, reactive oxygen species, and 1-chloro-4-nitrobenzene in high concentrations of chlorhexidine and in a mixture of chlorhexidine and calcium hydroxide," Journal of Endodontics, vol. 39, no. 5, pp. 664-668, 2013.

[31] Z. Mohammadi and P. V. Abbott, "The properties and applications of chlorhexidine in endodontics," International Endodontic Journal, vol. 42, no. 4, pp. 288-302, 2009.

[32] H. Babich, B. J. Wurzburger, Y. L. Rubin, M. C. Sinensky, and L. Blau, "An in vitro study on the cytotoxicity of chlorhexidine digluconate to human gingival cells," Cell Biology and Toxicology, vol. 11, no. 2, pp. 79-88, 1995.

[33] M. Giannelli, F. Chellini, M. Margheri, P. Tonelli, and A. Tani, "Effect of chlorhexidine digluconate on different cell types: a molecular and ultrastructural investigation," Toxicology in Vitro, vol. 22, no. 2, pp. 308-317, 2008.

[34] Y.-Y. Tu, C.-Y. Yang, R.-S. Chen, and M.-H. Chen, "Effects of chlorhexidine on stem cells from exfoliated deciduous teeth," Journal of the Formosan Medical Association, vol. 114, no. 1, pp. 17-22, 2015.

[35] S. Gao, S. Li, Z. Ma et al., "Presence of Porphyromonas gingivalis in esophagus and its association with the clinicopathological characteristics and survival in patients with esophageal cancer," Infectious Agents and Cancer, vol. 11, no. 1, article 3, 2016. 

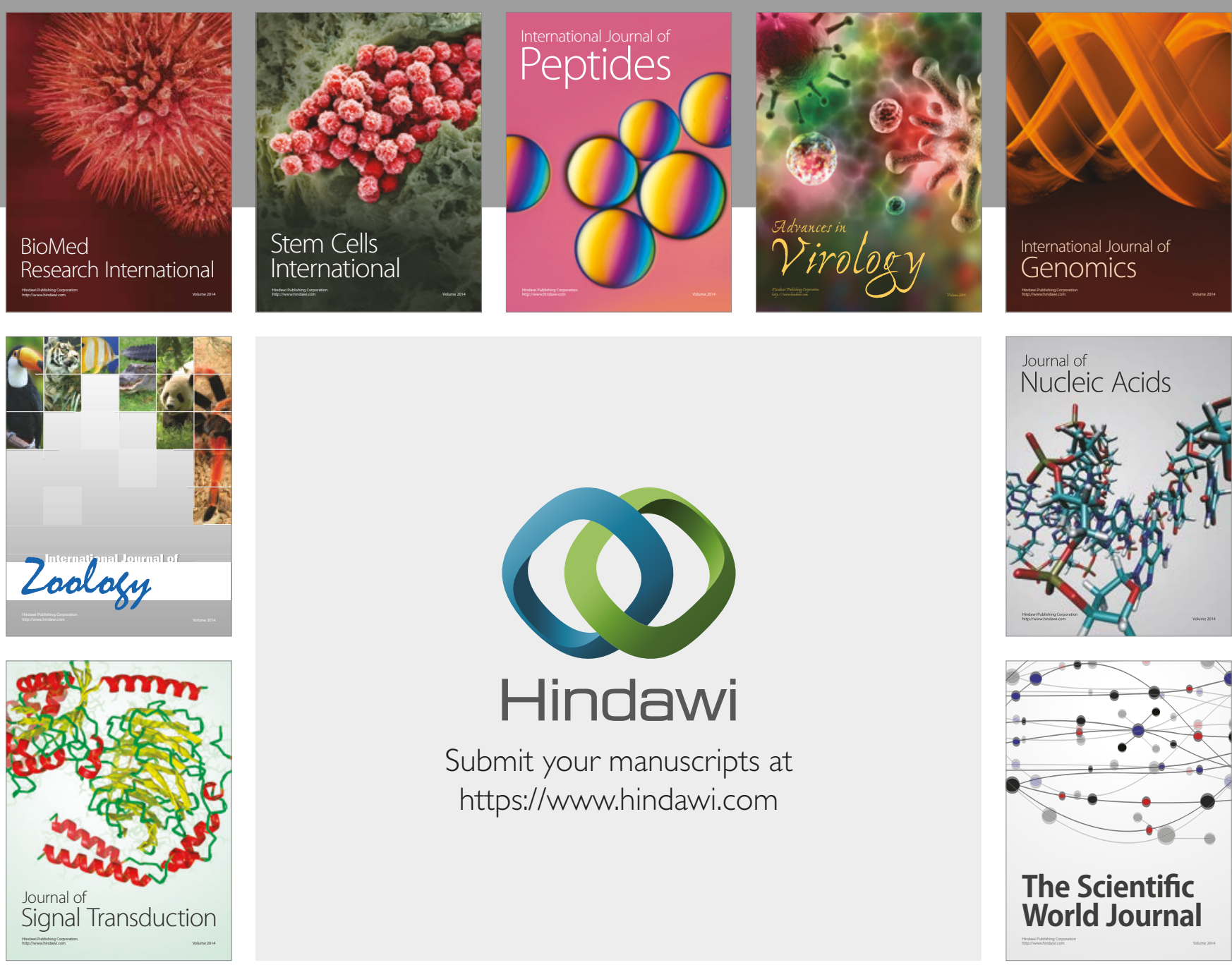

Submit your manuscripts at

https://www.hindawi.com
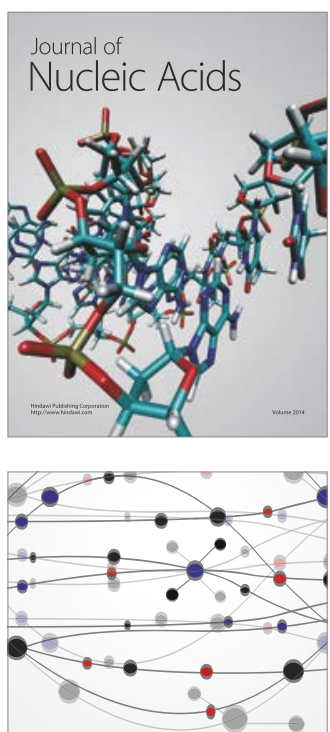

The Scientific World Journal

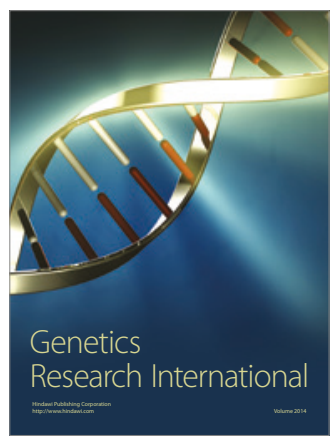

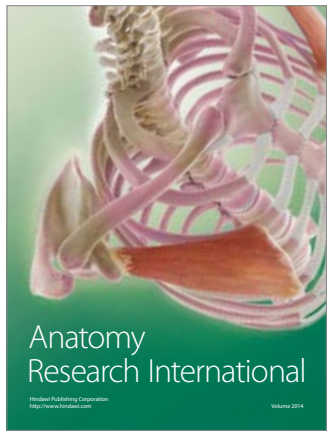

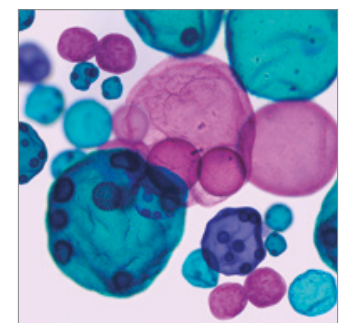

International Journal of Microbiology
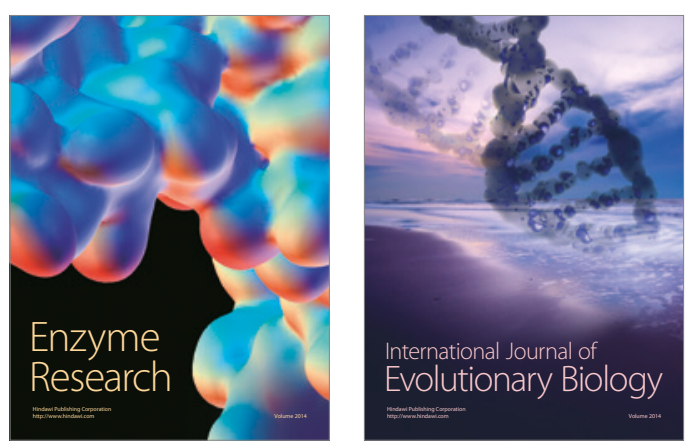
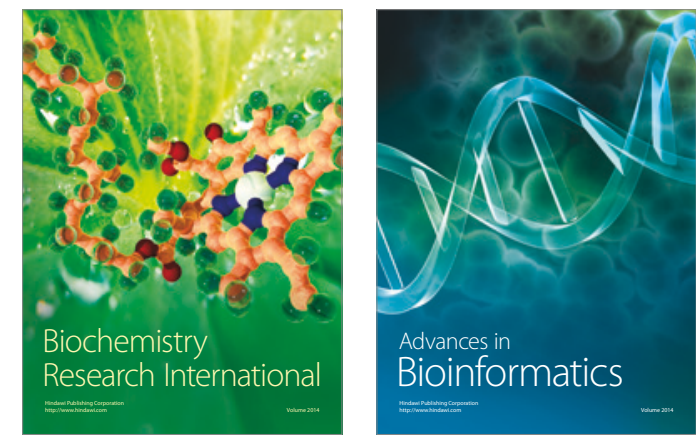

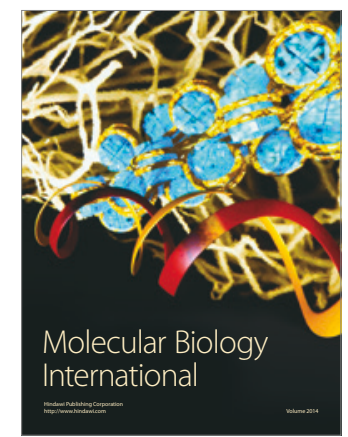

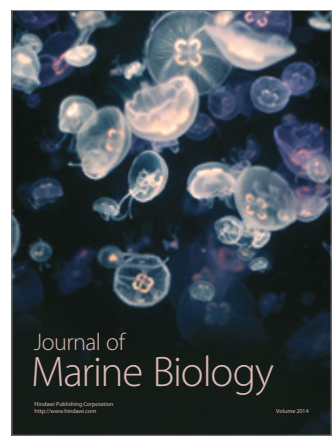

